\title{
Geochemical-Focusing of Manganese in Lake Sediments - An Indicator of Deep-Water Oxygen Conditions
}

\author{
TOBIAS SCHALLER* ${ }^{\star}$ and BERNHARD WEHRLI
}

Limnological Research Centre, Swiss Federal Institute for Environmental Sciences and Technology (EAWAG) and Swiss Federal Institute of Technology (ETH), CH-6047 Kastanienbaum, Switzerland

(Received: 22 October 1996; in final form: 11 February 1997)

\begin{abstract}
The lateral distributions of $\mathrm{Mn}$ concentrations in the sediments of two Swiss lakes under varying oxygen conditions have been determined. The comparison of 'Mn distribution patterns with oxygen in the deep-water provides strong evidence for a geochemical-focusing effect, which is driven by the redox cycle of manganese. Conditions essential for this process to occur are anoxic sediments in contact with oxic deep-water. Average sedimentary manganese concentrations determined for different water-depth ranges are directly proportional to the area of shallower sediments. This result indicates that geochemical-focusing of manganese in lake sediments is a promising proxy indicator for the reconstruction of oxygen conditions during deposition.
\end{abstract}

Key words: geochemical-focusing, manganese, redox conditions, lake sediment

\section{Introduction}

Manganese in lake sediments reacts sensitively to changes of redox conditions. The two oxidation states $\mathrm{Mn}(\mathrm{IV})$ and $\mathrm{Mn}(\mathrm{II})$, which are important in natural aquatic systems, show very different properties with respect to adsorption, complexation and solubility. The fate of manganese in lakes has recently been thoroughly reviewed by Davison (1993).

Temporal and spatial variations of redox conditions within a lake system induce an internal cycling of manganese (e.g. Balistrieri et al., 1992; Davison, 1993; Davison and Woof, 1984; Davison et al., 1982; Dean et al., 1981; François, 1988; Friedl et al., 1996; Wehrli et al., 1995a). Manganese released from the sediment by reductive dissolution is reoxidised within the oxic part of the water-column and subsequently redeposited. Due to the slow oxidation kinetics of dissolved $\mathrm{Mn}^{2+}$ in oxygenated waters (Chapnick et al., 1982; Tipping et al., 1984) hydrodynamic and morphological features can lead to distinct spatial patterns of sedimentary $\mathrm{Mn}$ concentrations. Horizontal distribution patterns of sedimentary manganese have been reported for several lakes. In Lake Constance Ostendorp and Frevert (1979) observed two distinct regions near the central part of the lake with increased Mn

* Author for correspondence. 
concentrations. This observation was attributed to differential settling of Mn bearing particles along intrusions induced by the plunging river Rhine and transport of $\mathrm{Mn}^{2+}$ released from the anoxic deep sediments by bottom currents, which are caused by the inflowing river. The deep-water sediments of Esthwaite-Water were found to be depleted in manganese (Davison, 1993; Hamilton-Taylor and Morris, 1985). Seasonally anoxic conditions in the hypolimnion and a short hydraulic residence time of only 13 weeks in this shallow lake lead to a loss of manganese from the deep-water sediments through the outflow. Tessenow (1976) observed a small scale redistribution of sedimentary manganese in the vicinity of a seasonally developing oxycline. Takamatsu et al. (1985) postulated, that the increase of sedimentary $\mathrm{Mn}$ concentrations in a deep lake is due to a greater chance of $\mathrm{Mn}^{2+}$ released from anoxic sediments at shallow regions to be transported via the outflow.

These examples indicate that $\mathrm{Mn}$ concentration patterns in sediments are controlled by different physical and chemical mechanisms. The term "geochemical focusing", used in this paper, stands for a sequence of redox reactions and transport mechanisms which increase the concentration in the sediment with water-depth.

The study was designed to assess these geochemical effects on the two-dimensional distribution of $\mathrm{Mn}$ in lake sediments. In order to minimise physical factors such as turbidity currents induced by inflows or removal of dissolved manganese by the outflow, this study was conducted in two deep lakes with long hydraulic residence times (Baldeggersee and Zugersee, Switzerland). The two lakes changed from mesotrophic to highly eutrophic during the last hundred years. Time series of oxygen concentrations in the deep-water are available since 1950.

The horizontal and vertical distribution of $\mathrm{Mn}$ in the sediments of the hypolimnion was determined and correlated with the oxygen records in both lakes. This approach allowed us to address the question whether geochemical-focusing of $\mathrm{Mn}$ can be used as a proxy-indicator for the reconstruction of oxygen concentrations in the water-column.

\section{Study Sites}

Two prealpine hardwater lakes in Central Switzerland (Baldeggersee and Zugersee) were chosen for this study.

The lake Zugersee (Figure 1b), located $30 \mathrm{~km}$ south of Zurich, is subdivided into a shallow North Basin and a deep South Basin by a conglomerate ridge, the Chiemen peninsula. The North Basin slopes gently from a shallow $(40-60 \mathrm{~m})$ sedimentary plain towards the deep $(200 \mathrm{~m})$ flat lying plain in the South Basin, which has very steep slopes $\left(20-45^{\circ}\right)$ and a narrow littoral zone. In contrast to the North Basin, that lies open with respect to prevailing wind directions, the South Basin is sheltered by mountains ( $400-1400 \mathrm{~m}$ above lake level). Discharge from Zugersee averages $7-8 \mathrm{~m}^{3} \mathrm{~s}^{-1}$, causing a long hydraulic residence time of 14 years. Kelts (1978) found several intervals of varved sediments indicating that 
anoxic conditions in the deep-water of the South Basin occurred periodically over the last 4000 years.

Today Zugersee is highly eutrophic. The South Basin is meromictic, due to chemical stratification. Oxygen is seldom transported deeper than $180 \mathrm{~m}$, even during storm events in spring (Wehrli et al., 1995b). On the other hand, most parts of the water column of the North Basin are well mixed during spring turnover. However, due to increased sedimentation rates of particulate organic carbon during the last decades, nitrate is completely depleted within a few centimetres above the sediment-water interface. These observations indicate that the sediment surface itself is anoxic (Mengis et al., submitted).

The lake Baldeggersee (Figure la), located $16 \mathrm{~km}$ north of Lucerne, has a more even morphology than Zugersee. From a deep flat plain in the middle of the lake the slopes are gently rising towards the shore. The relation between the catchment area and the lake surface area is very small (13:1) resulting in a long hydraulic residence time of approx. 4.5 years (Niessen and Sturm, 1987). The catchment area, used for intense agricultural production, is drained by several small creeks. On its eastern and western shores, the lake is surrounded by hills reaching about $300 \mathrm{~m}$ above the lake surface. They efficiently shield the lake from West-winds. Since the end of the last century the lake became increasingly eutrophic (Niessen and Sturm, 1987). Phosphorus concentrations in the water-column steadily increased from 1950 until 1974 when they reached a maximum of $0.55 \mathrm{mg} \mathrm{1}^{-1}$. By 1990 the concentrations had decreased to $0.07 \mathrm{mg}^{-1}$, mainly due to the installation of sewage treatment plants.

Parallel to the phosphorus loading, the oxygen history of Baldeggersee is well documented since 1950 and makes it an ideal test site to study the response of sedimentary manganese to changing oxygen conditions. Since 1982, Baldeggersee has been artificially aerated. This measure changed deep-water oxygen concentrations in a dramatic way, as is shown in Section 4.1.1.

\section{Sampling and Analytical Methods}

In October 199238 short cores (up to $90 \mathrm{~cm}$ long) were taken in Baldeggersee (Figure 1a) and in July 199312 stations were sampled in Zugersee (Figure 1b) with a gravity corer of $6.3 \mathrm{~cm}$ diameter. The coring technique is described in Kelts et al. (1986). The short cores were stored at $4{ }^{\circ} \mathrm{C}$ in PVC-tubes and subsequently opened by cutting the cores into two halves for stratigraphic analysis and sampling.

The stratigraphy of the 38 cores from Baldeggersee showed three distinct layers (Figure 2): (1) Grey homogeneous marl at the bottom of the cores, followed by (2) a section of biogenic varves and at the top (3) a dark brown, more or less homogeneous layer. Each of these distinct layers was sampled in every core, by taking a slice of $2 \mathrm{~cm}$ near the top of the respective layer. 

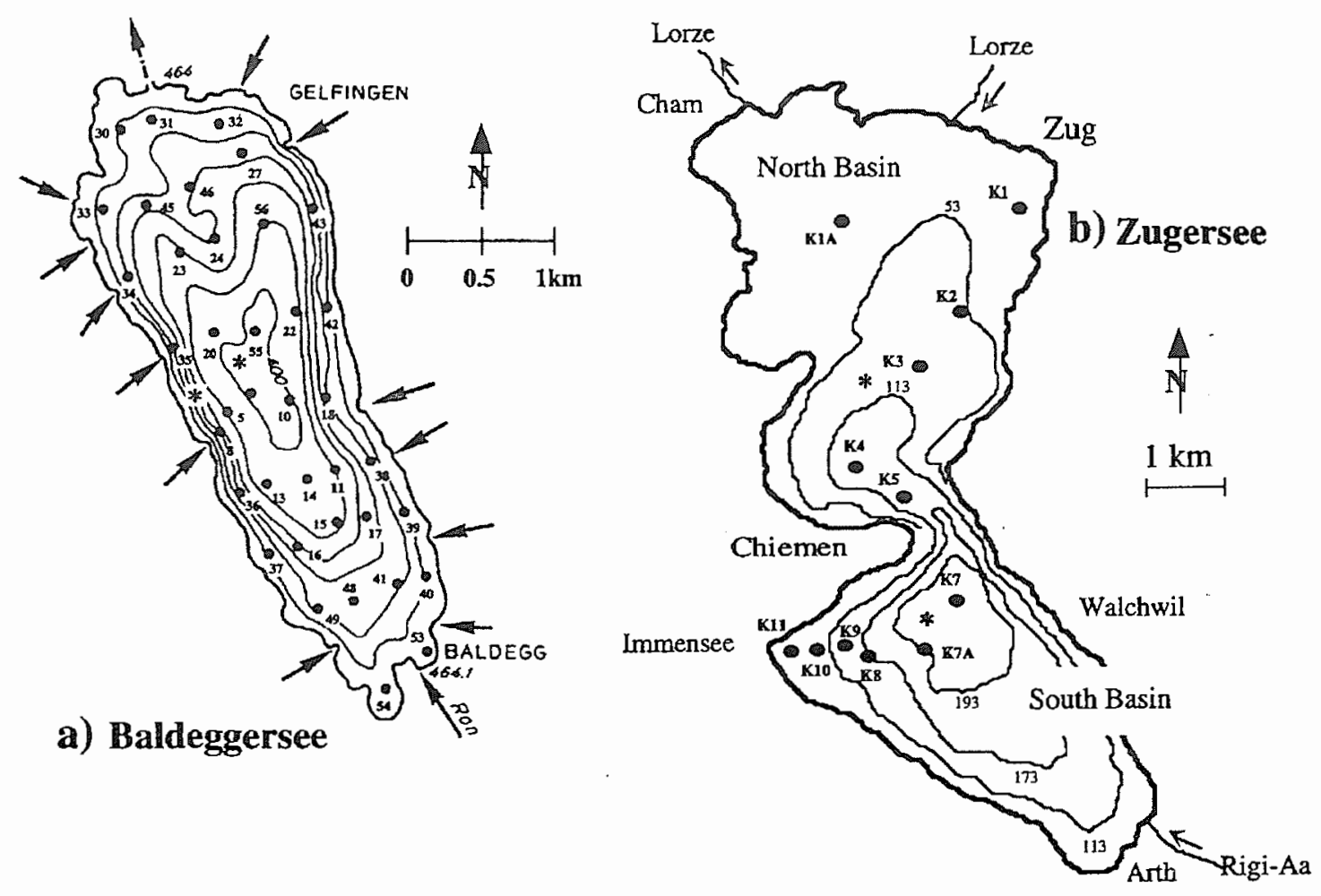

Figure 1. Dots indicate the approximate positions of cores taken in Baldeggersee (a) and Zugersee (b). Stars indicate the approximate positions of pore-water sampling stations. The morphometry is given in intervals of $10 \mathrm{~m}$ and $50 \mathrm{~m}$ for Baldeggersee and Zugersee, respectively. Arrows indicate in- and outflows.

All cores from Zugersee were sampled with a resolution of half a centimetre down to a depth of $15 \mathrm{~cm}$, which includes approximately the last 35-40 years (Kelts, 1978; Wehrli et al., 1995b).

All samples were freeze dried with a Leybold Heraeus Lyvac GTZ and then homogenised in an agate mortar. A portion of $50 \mathrm{mg}$ was digested with $4 \mathrm{ml}$ $65 \%$ nitric acid (Merck suprapur) and $1 \mathrm{ml}$ of 30\% hydrogen peroxide (Merck suprapur) in a pressure tube in a Milestone mls 1200 mega microwave oven. Parallel digestion of several samples with hydrofluoric acid showed that more than $98 \%$ of the particulate manganese was dissolved with our procedure.

Mn concentrations were measured either with a Flame-AAS (Perkin Elmer AAS 2100 ) in case of the sediment samples from Baldeggersee, or with an ICP-OES (Spectro) in case of the sediment samples from Zugersee. The overall relative error of sample treatment and concentration measurements was estimated by replicate digestion to be less than $3 \%$.

Pore-water profiles were collected using dialysis samplers (Urban et al., submitted) in November 1992 at Baldeggersee and in January 1993 at Zugersee. Manganese concentrations were determined with an ICP-OES (Spectro).

The interpolation of the 1992 data set was performed with the software package "Transform" (Spyglass Inc.) using Kriging interpolation functions. For each interpolation all 38 samples were used. Range and number of samples per Kriging 


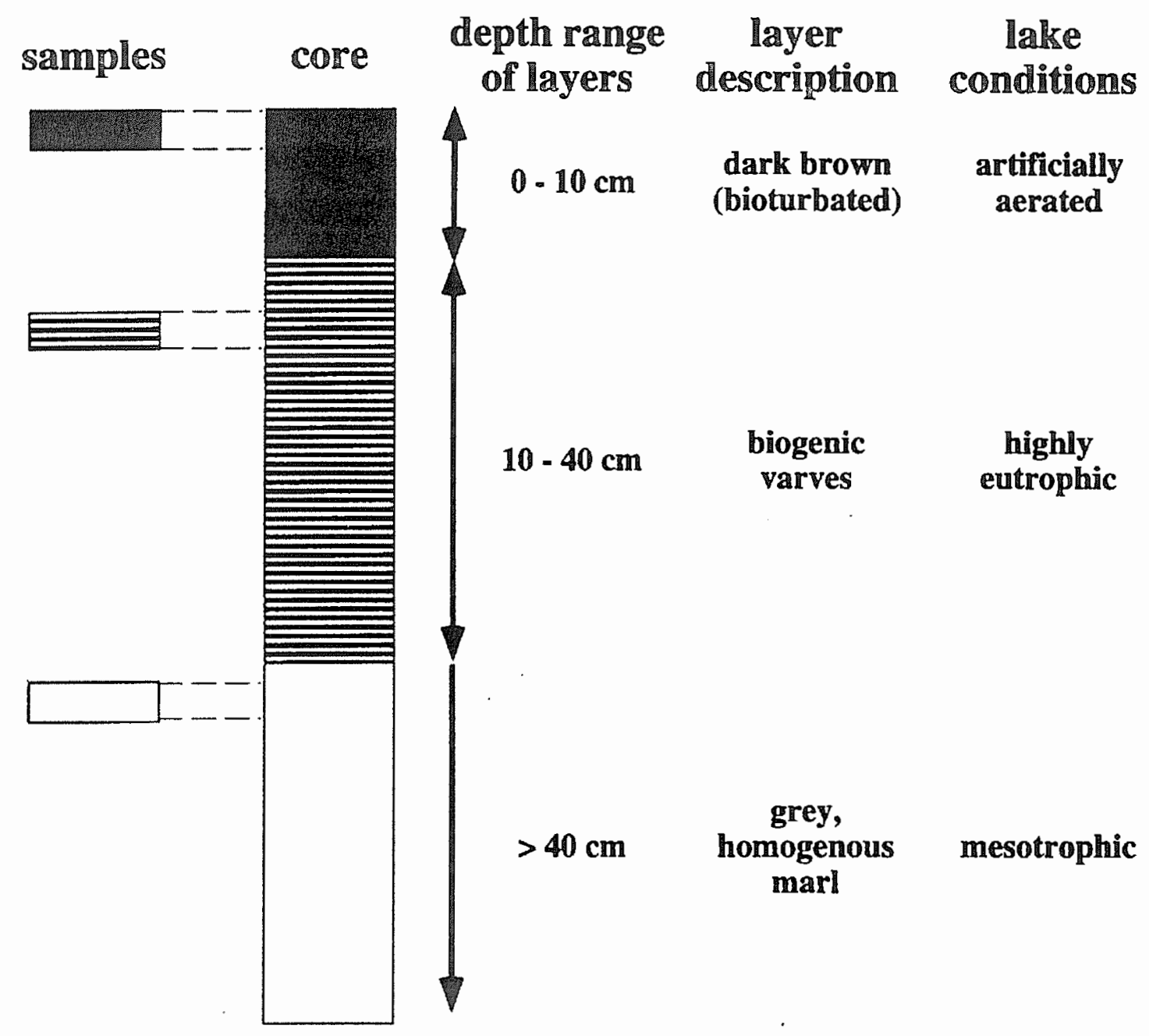

Figure 2. Stratigraphic scheme of the 38 sediment cores from Baldeggersee and the resulting sampling strategy. Lake conditions are associated to sediment layers.

pass were chosen such, that at least 5 neighbouring fixpoints were used to determine interpolated values. The variance was set to 1.0 , the nugget to 0.0 . Values at fixpoints were recalculated during interpolation and averaged. A comparison between calculated and measured values showed differences between $5-20 \%$. This accuracy is acceptable, because the interpolations are used only to outline general trends in the two dimensional distribution.

Oxygen concentrations have been determined within governmental lake survey programs. Concentrations were measured using the Winkler method.

\section{Results}

\subsection{OXYGEN BUDGETS AND SEDIMENTS}

\subsubsection{Baldeggersee}

Figure 3a presents an outline of the available oxygen data in the hypolimnion. Average concentrations below a depth of $20 \mathrm{~m}$ were calculated from oxygen profiles 
at a central station for both spring (February-April) and autumn (SeptemberOctober) conditions. The period from 1950 to 1982 is marked by low average oxygen concentrations $\left(<3 \mathrm{mg} \mathrm{l}^{-1}\right)$ in the hypolimnion during autumn. In most years spring oxygen conditions were also low due to incomplete deep-water mixing. From 1960 to 1980, a period of extremely high phosphorus loading, the oxygen levels never exceeded $\sim 4 \mathrm{mg}^{-1}$ during spring. Periods with such low average oxygen concentrations in spring are equivalent to a partially anoxic deep-water. The response of the sediment to these redox conditions is clearly shown by its stratigraphy (Figure 2): undisturbed biogenic varves reflect stable anoxic conditions in the deep-water. In their sedimentological study Niessen and Sturm (1987) showed that biogenic varve formation has occurred at the deep flat plain since 1885. Until 1940 reducing conditions were restricted to the deeper parts of the lake $(>40 \mathrm{~m})$. From the end of the sixties until 1982 oxygen depletion could even be found in sediments at water-depth of only $10 \mathrm{~m}$.

Since 1982 the oxygen budget of Baldeggersee has been widely influenced by the artificial aeration. In general oxygen concentrations in the hypolimnion are now well above $4 \mathrm{mg} \mathrm{l}^{-1}$ during the whole year. Effects of the artificial aeration were visible in sediment cores taken at water-depths of less than $50 \mathrm{~m}$. The colour of the sediment in the top 4 to $10 \mathrm{~cm}$ changed from black to dark brownish and varves were disturbed or even absent (Figure 2). A biological study has shown that the sediments have been recolonised by Oligochaetae and Chironomidae down to a depth of $55 \mathrm{~m}$ (Spengeler, 1994). Oxygen profiles determined with dialysis samplers (peepers) showed that a concentration of about $0.25 \mathrm{mM}$ was maintained until approximately $10 \mathrm{~cm}$ above the sediment. At the sediment-water-interface oxygen concentrations are below detection limits $\left(<0.1 \mathrm{mg}^{-1}\right.$; Mengis et al., submitted).

The grey homogeneous marl at the bottom of each core was deposited under mesotrophic lake conditions (Niessen and Sturm, 1987). Evidence is given that the degradation of particulate organic matter at the sediment-water interface occurred under oxic conditions: (1) Average $\mathrm{C}_{\text {org }}$ concentrations in the grey marl (22 \pm $\left.8 \mathrm{mg} \mathrm{g}^{-1}\right)$ are lower than in the varved $\left(31 \pm 7 \mathrm{mg} \mathrm{g}^{-1}\right)$ layer. By using a t-test, the hypothesis that Corg levels of the grey marl and the varved layer follow the same distribution (Null hypothesis) can be rejected on a $95 \%$ confidence level (unpublished data). (2) Low sulphide concentrations $\left(<4 \mu \mathrm{mol} \mathrm{g}^{-1}\right)$ in the grey marl in contrast to the varved layer $\left(60-200 \mu \mathrm{mol} \mathrm{g}^{-1}\right.$ ) (Jödike, 1996) and the colour of the marl suggest that the organic matter was not degraded by sulphate reduction. (3) The homogeneity of the sediment suggests intense bioturbation, which increases the flux of oxygen from the water-column to the sediment. Summarising, the simple stratigraphy outlined in Figure 2 can be attributed to three different oxygen regimes:

(a) Mesotrophic lake with an oxic water-column. The sediments are bioturbated and show a homogeneous grey marl. Oxygen may well penetrate into the sediment due to bioturbation. 

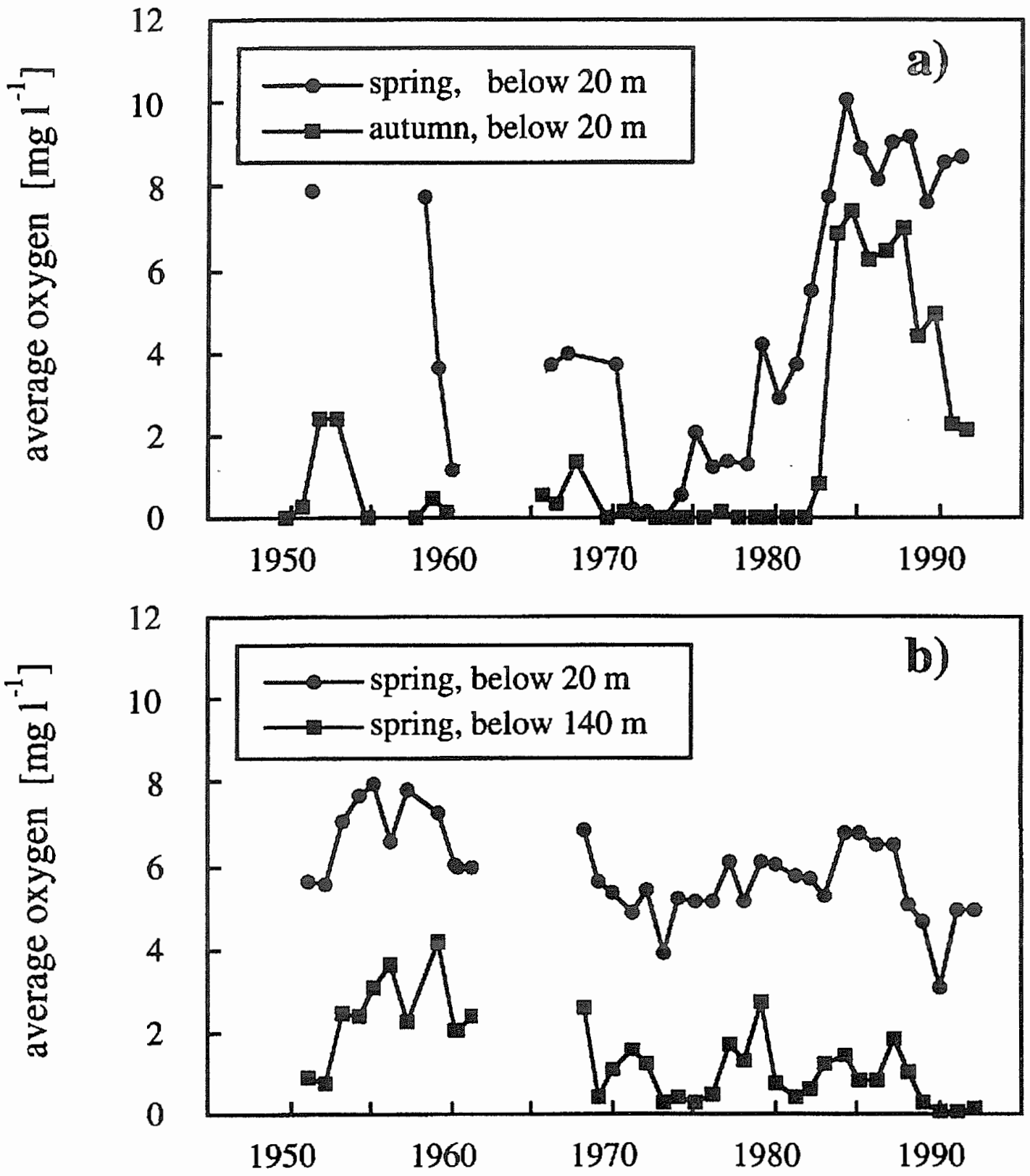

Figure 3. Average oxygen concentrations in the deep-water of Baldeggersee (a) and Zugersee (b). The average was determined by weighting concentrations from oxygen profiles with the respective water-volume as a function of depth. For Baldeggersee, oxygen concentrations between 1960 and 1982 apply to the sample from the varved layer (Figure 2), oxygen conditions between 1984 and 1991 apply to the samples from the dark brown layer.

(b) Highly eutrophic lake with anoxic deep-water. Since no benthic animals are present, the biogenic varves are well preserved.

(c) Eutrophic lake with artificial aeration. The productivity is still high, but the anoxic sediment surface is in contact with an oxygenated hypolimnion. Bioturbation prevents the preservation of seasonal layers, except at the deep plain (> $50 \mathrm{~m}$ water-depth). 


\subsubsection{Zugersee}

The North Basin of Zugersee never developed extremely anoxic conditions in the deep-water, because it is not shielded from the main wind directions. But in the deep flat plain of the South Basin an anoxic water-column of more than $40 \mathrm{~m}$ has developed since the sixties (Figure $3 b$ ), caused by the mixing boundary conditions and the chemical stratification of the bottom waters. The chemical stratification is set off by the dissolution of $\mathrm{CaCO}_{3}$ and biogenic silica (diatoms) at the sedimentwater interface and subsequent diffusion into the water-column (Wehrli et al., 1995b). Average oxygen concentrations between 140 and $200 \mathrm{~m}$ water-depth in the South Basin have generally remained well below $2 \mathrm{mg}^{-1}$ since the late sixties.

In terms of oxygen budgets Zugersee and Baldeggersee are complementary systems: Baldeggersee exhibits a well documented abrupt change in oxygen concentrations in 1982. Zugersee on the other hand shows a clear gradient from the well oxygenated North Basin down to the completely anoxic deep part of the South Basin.

The sediment cores from Zugersee show a similar stratigraphy as those from Baldeggersee. At the bottom of all cores (approx. 20-90 cm) a light grey, more or less homogeneous marl was found. The top of each core $(0-16 \mathrm{~cm})$ consisted of a black, organic rich sediment. A transitional interval of approximately $4 \mathrm{~cm}$ thickness consists of a dark grey sediment often containing single small black layers. Unlike Baldeggersee typical biogenic varves were only found in cores overlain by a water column of more than $90-100 \mathrm{~m}$. In the deeper parts of the South Basin the cores gave evidence for turbidite layers and internal slumping, due to the very steep slopes.

\subsection{MANGANESE DISTRIBUTION IN SEDIMENTS}

\subsubsection{Baldeggersee}

Mn concentrations were analysed in all 38 short cores taken in 1992. Figure 4 outlines the results of Kriging interpolations for the three sediment layers. The grey marl at the bottom of the cores was deposited before 1885 and represents mesotrophic lake conditions (Figure 2). The Mn concentrations in the grey marl show a rather uniform distribution (Figure 4a). There is only a slight increase in the northern part of the lake where the water is shallower.

The horizontal distribution of $\mathrm{Mn}$ concentrations in the varved sediment layer, accumulated under bottom water anoxia (highly eutrophic lake conditions), are different from the grey marl (Figure 4b, Table I). The shallow parts are slightly depleted in manganese while sediments in the deepest part are enriched.

The trend towards higher concentrations at the deepest site is accentuated in the samples from the dark brown layer (artificially aerated lake conditions) (Figure 4c). The littoral sediments are even more depleted in manganese than in the highly eutrophic situation and very high concentrations are found at greatest depth. The 
Table I. Mn concentrations of each sample from Baldeggersee, average, minimal and maximal values, standard-deviations

\begin{tabular}{|c|c|c|c|c|}
\hline \multirow{2}{*}{$\begin{array}{l}\text { Water-depth } \\
\text { (m) }\end{array}$} & \multirow{2}{*}{$\begin{array}{l}\text { Core } \\
\text { number }\end{array}$} & \multicolumn{3}{|c|}{$\begin{array}{l}\text { Mn-concentrations }\left[\mathrm{mg} \mathrm{g}^{-1}\right] \text { in the } \\
\text { sediment layers }\end{array}$} \\
\hline & & grey marl & biogenic varves & dark brown \\
\hline 7 & 53 & 0.40 & 0.40 & 0.30 \\
\hline 10 & 54 & 0.16 & 0.17 & 0.23 \\
\hline 12 & 40 & 0.30 & 0.27 & 0.18 \\
\hline 14 & 30 & 0.52 & 0.34 & 0.14 \\
\hline 14 & 37 & 0.28 & 0.12 & 0.01 \\
\hline 14 & 39 & 0.58 & 0.11 & 0.03 \\
\hline 16 & 31 & 0.59 & 0.22 & 0.18 \\
\hline 16 & 33 & 0.12 & 0.25 & 0.05 \\
\hline 16 & 42 & 0.34 & 0.05 & 0.13 \\
\hline 18 & 32 & 0.33 & 0.21 & 0.17 \\
\hline 23 & 34 & 0.30 & 0.23 & 0.09 \\
\hline 23 & 35 & 0.39 & 0.18 & 0.15 \\
\hline 23 & 38 & 0.33 & 0.25 & 0.19 \\
\hline 23 & 49 & 0.38 & 0.24 & 0.10 \\
\hline 24 & 41 & 0.45 & 0.21 & 0.43 \\
\hline 28 & 18 & 0.39 & 0.22 & 0.11 \\
\hline 28 & 43 & 0.38 & 0.13 & 0.08 \\
\hline 30 & 27 & 0.29 & 0.35 & 0.27 \\
\hline 30 & 45 & 0.28 & 0.28 & 0.15 \\
\hline 32 & 46 & 0.50 & 0.31 & 0.22 \\
\hline 33 & 8 & 0.25 & 0.27 & 0.23 \\
\hline 33 & 24 & 0.86 & 0.34 & 0.21 \\
\hline 33 & 48 & 0.28 & 0.24 & 0.22 \\
\hline 35 & 36 & 0.35 & 0.20 & 0.35 \\
\hline 37 & 17 & 0.30 & 0.23 & 0.26 \\
\hline 40 & 16 & 0.29 & 0.31 & 0.23 \\
\hline 43 & 23 & 0.62 & 0.19 & 0.29 \\
\hline 51 & 15 & 0.34 & 0.29 & 0.30 \\
\hline 53 & 5 & 0.34 & 0.30 & 0.52 \\
\hline 53 & 11 & 0.40 & 0.25 & 0.27 \\
\hline 53 & 56 & 0.41 & 0.33 & 0.39 \\
\hline 54 & 13 & 0.42 & 0.35 & 0.42 \\
\hline 55 & 22 & 0.44 & 0.39 & 0.45 \\
\hline 57 & 14 & 0.39 & 0.51 & 0.36 \\
\hline 58 & 20 & 0.46 & 0.48 & 0.43 \\
\hline 63 & 4 & 0.57 & 0.52 & 0.64 \\
\hline 64 & 10 & 0.49 & 0.45 & 0.52 \\
\hline 67 & 55 & 0.63 & 0.87 & 2.25 \\
\hline average & & 0.40 & 0.29 & 0.30 \\
\hline minimal & & 0.12 & 0.05 & 0.01 \\
\hline maximal & & 0.86 & 0.87 & 2.25 \\
\hline stand. dev. & & 0.14 & 0.14 & 0.36 \\
\hline
\end{tabular}



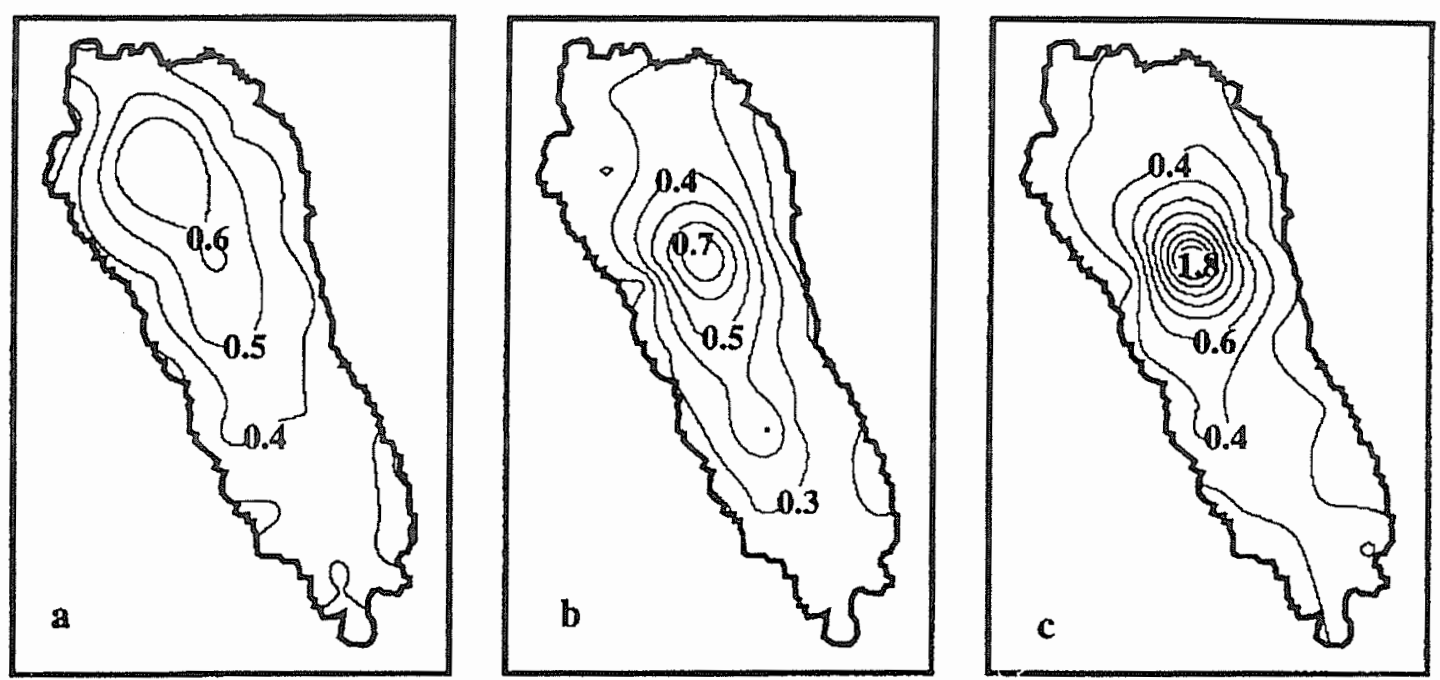

Figure 4. Horizontal distribution of Mn-concentrations $\left[\mathrm{mg} \mathrm{g}^{-1}\right]$ in the sediment of Baldeggersee. The graphs represent a Kriging interpolation of 38 stations sampled at sediment horizons which correspond to mesotrophic (a), highly eutrophic (b) and artificially aerated (c) lake conditions.

larger variability is also shown by comparing highest and lowest concentrations (Table I). Measurements of $\mathrm{Ca}$ and $\mathrm{C}_{\text {org }}$ have verified that dilution cannot account for this effect (unpublished data).

\subsubsection{Zugersee}

Manganese profiles in the cores from the two transects in Zugersee show a clear increase of average concentrations with water-depth. Figure 5 compares the $\mathrm{Mn}$ concentrations in the top $15 \mathrm{~cm}$ of each core. Average Mn concentrations are increasing from the littoral zone to the deepest parts by a factor of 4 in both transects. However, below the oxycline at $160 \mathrm{~m}$ in the South Basin the enrichment stops: core $8(158 \mathrm{~m})$ and core $7 \mathrm{~A}(190 \mathrm{~m})$ show comparable average concentrations $\left(0.71 \pm 0.09 \mathrm{mg} \mathrm{g}^{-1}\right.$ and $0.73 \pm 0.1 \mathrm{mg} \mathrm{g}^{-1}$, respectively).

The profile of core 5 is characterised by a strong subsurface maximum, the origin of which is unknown. However, the sites of cores 4 and 5 are strongly influenced by bottom currents. Singular strong wind events (thunderstorms) generate internal waves, which produce horizontal currents in the hypolimnion. The decreasing cross section at the peninsula increases current velocities according to mass conservation. The sediment composition near the channel is greatly influenced by these bottom currents: Resuspension of organic matter and clay particles leads to a 7 -fold decrease of the net sedimentation rate of core 5 , as was shown by ${ }^{137} \mathrm{Cs}$ measurements and particle size distribution (Moor et al., 1996). We therefore excluded these two cores from our final analysis. 

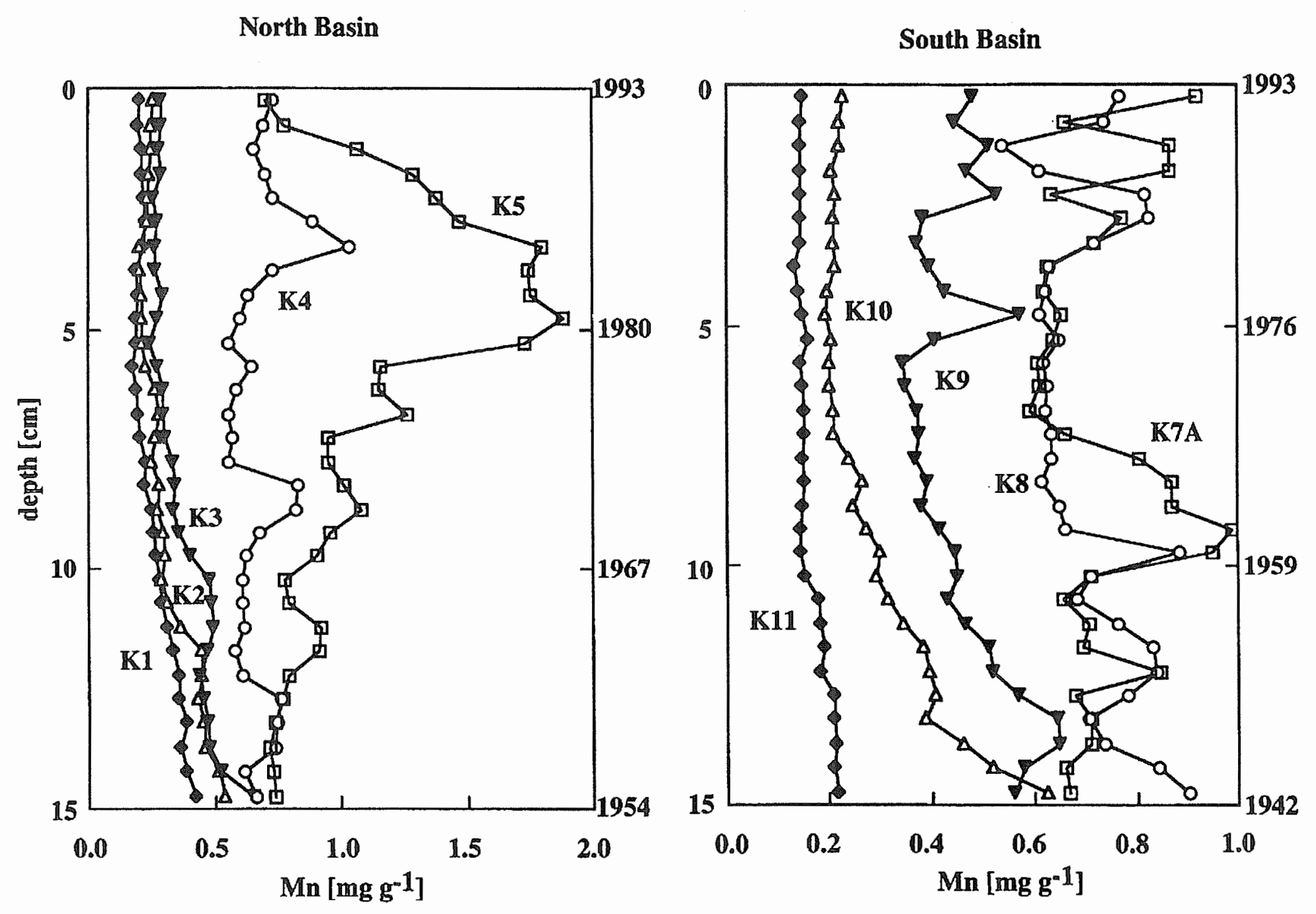

Figure 5. Mn concentration plotted against sediment depth and estimated age in the two core transects from Zugersee. The age determination is not valid for core 4 and 5 . 


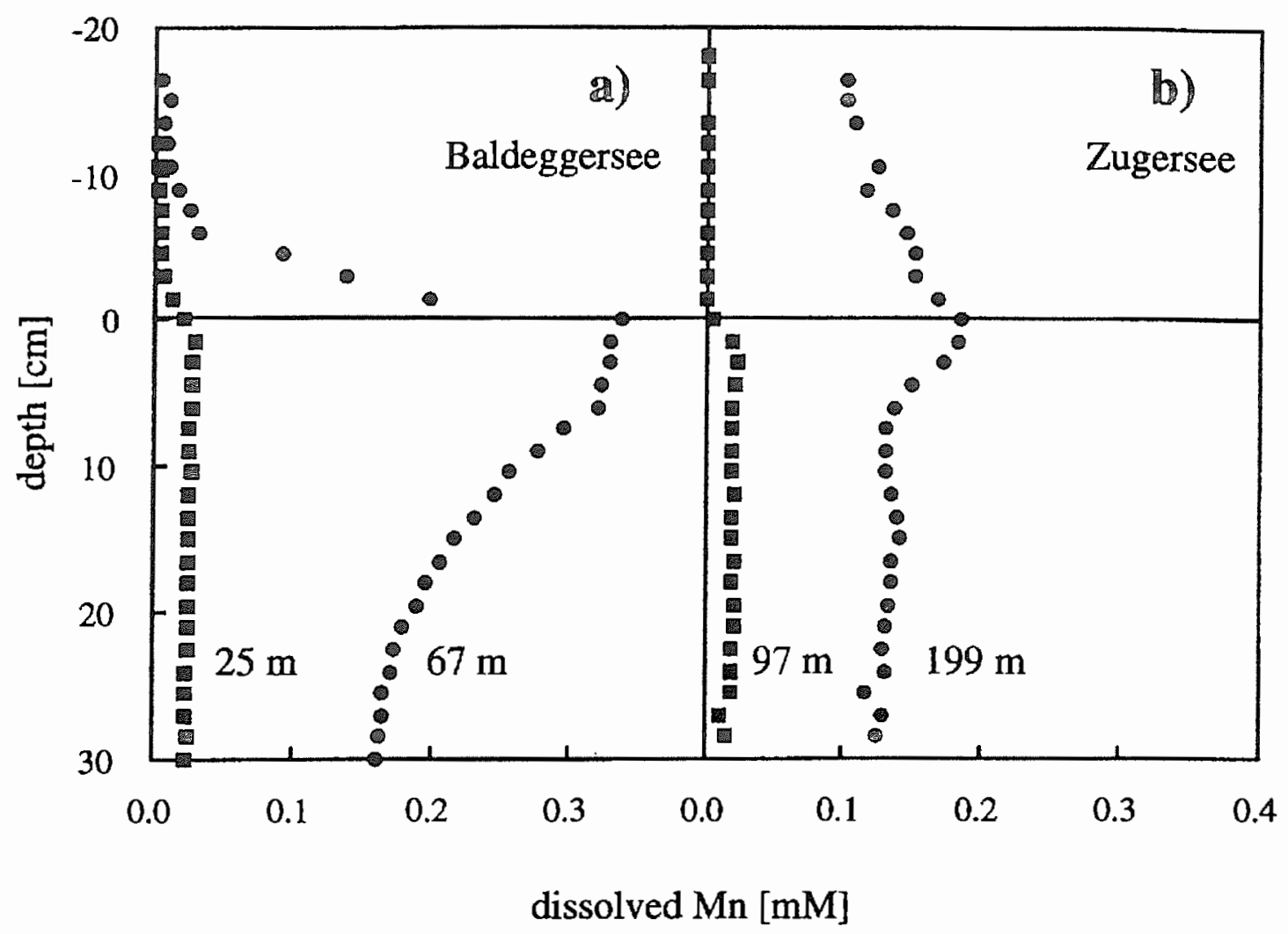

Figure 6. Pore water profiles of manganese in Baldeggersee (November 1992) and Zugersee (January 1993), obtained with in-situ dialysis samplers.

\subsection{PORE-WATER PROFILES}

The increase of $\mathrm{Mn}$ concentrations with water-depth is also reflected in the porewater profiles of both lakes. Figure 6 compares the station at the deepest site with one at shallower depth during winter conditions. In both cases, the profiles from the central stations show a concentration maximum near the sediment-water interface. This indicates intense reductive dissolution to act as a source for $\mathrm{Mn}^{2+}$ in the pore-water. Diffusive flux rates have been determined from the pore-water profiles. At the deepest station of Baldeggersee the manganese release into the overlying water was $300 \mu \mathrm{mol} \mathrm{m}^{-2} \mathrm{~d}^{-1}$ compared to only $19 \mu \mathrm{mol} \mathrm{m}^{-2} \mathrm{~d}^{-1}$ at the littoral site. A similar increase of diffusive fluxes with water-depth has been observed in Sempachersee, $30 \mathrm{~km}$ West of Baldeggersee (Wehrli et al., 1995a). A quantitative sediment trap study during four years showed that the average Mn sedimentation was 72 and $970 \mu \mathrm{mol} \mathrm{m}^{-2} \mathrm{~d}^{-1}$ at 20 and $81 \mathrm{~m}$ depth, respectively (Wehrli et al., 1995a).

The concentration maximum of the pore-water profiles at the sediment-water interface produce an additional flux of dissolved manganese into the deeper sediment. At the deepest site of Baldeggersee this flux has been estimated as $30 \mu \mathrm{mol} \mathrm{m}^{-2}$ $\mathrm{d}^{-1}$. This amounts to about $50 \%$ of the Mn accumulation rate at this site (Schaller et al., unpublished results). Similar profiles have been observed during other times of the year, which indicates that authigenic formation of $\mathrm{Mn}$ (II) minerals in deeper 
sediment layers is an important sink for dissolved $\mathrm{Mn}^{2+}$. At both central stations, the concentration of $\mathrm{Mn}^{2+}$ below $15 \mathrm{~cm}$ is about 5 times higher than at the littoral stations, which parallels the increase in the solid concentration. This correlation between dissolved and solid phase suggests that solid solutions like $(\mathrm{Ca}, \mathrm{Mn}) \mathrm{CO}_{3}$ or (Fe,Mn $)_{3}\left(\mathrm{PO}_{4}\right)_{2}$ (Calvert and Price, 1977; Calvert and Pedersen, 1993; Friedl et al., 1996) control the accumulation of $\mathrm{Mn}(\mathrm{II})$ in these anoxic sediments.

In both lakes stagnant conditions are evident at the deepest site. The meromictic deep-water of Zugersee has accumulated dissolved Mn concentrations of $0.1 \mathrm{mM}$ and in Baldeggersee the $\mathrm{Mn}$ gradient extends into the overlying water. Due to the stagnant conditions in the water column higher Mn concentrations can build up in the pore-water. This accelerates the formation of authigenic minerals.

\section{Discussion}

\subsection{A CONCEPTUAL MODEL FOR THE GEOCHEMICAL-FOCUSING OF MANGANESE IN LAKES}

A model of the geochemical-focusing of manganese should explain what was observed in Baldeggersee and Zugersee:

(1) Geochemical-focusing of manganese is negligible in a mesotrophic lake where reductive dissolution of $\mathrm{Mn}$ oxides at the sediment-water interface is restricted due to oxygen penetration into the sediment.

(2) Geochemical-focusing occurs in deep, eutrophic lakes with long hydraulic residence times.

(3) Geochemical-focusing stops at a permanent oxic-anoxic boundary in the deepwater.

(4) Geochemical-focusing is intensified if oxygen conditions in the deep-water are changed by artificial aeration.

Figure 7 outlines schematically the important processes that may explain our observations. The "mesotrophic" scenario in Figure 7a represents a situation where small fluxes of $\mathrm{C}_{\text {org }}$ to the sediment, intense bioturbation and a well oxygenated water-column allow oxic conditions at the sediment-water interface. Under such conditions the predominant forms of manganese are insoluble Mn(IV)oxyhydroxides (Calvert and Pedersen, 1993; Davison, 1993; Lind et al., 1987). Mn(II) released to the pore-water in deeper parts of the sediment by reductive dissolution is reoxidised within the sediment (Thamdrup et al., 1994): The cycling of manganese is restricted to the sediment itself. In this case authigenic processes do not play an important role for the lateral redistribution of manganese in the sediment. Horizontal variations in the concentration of manganese are mainly controlled by differences in the sedimentation regime of allochthonous particles. Similarly a stable anoxic zone in a deep eutrophic lake such as the South Basin of Zugersee will not produce a significant geochemical-focusing effect (Figure 7b). In such a system a gradient of $\mathrm{Mn}^{2+}$ builds up in the water-column (Balistrieri et al., 1992.b; Davison et al., 1982; Davison, 1993; De Vitre et al., 1988; Spencer and Brewer, 


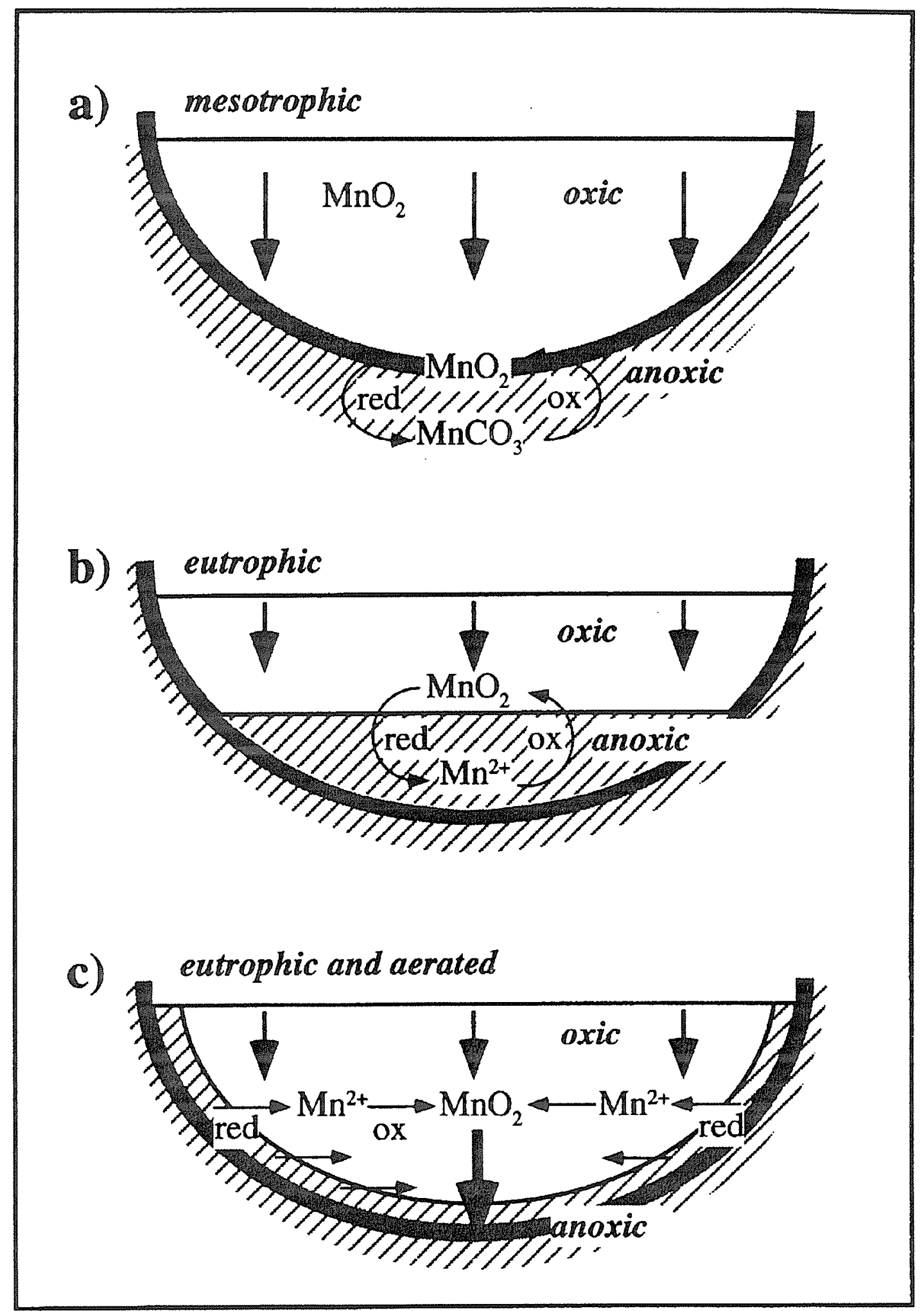

Figure 7. Conceptual model for the internal cycling of manganese under different oxygen conditions. 
1971). Manganese is oxidised at the oxycline and reprecipitated (Balistrieri et al., 1992b; Davison, 1993; Tipping et al., 1984).

However, geochemical-focusing is expected to occur in systems where the sediment-water interface remains anoxic but is in contact with an oxic watercolumn. In this case $\mathrm{Mn}^{2+}$ also diffuses out of the sediment (Figure 6). The fate of dissolved $\mathrm{Mn}$ in the water-column depends on its half life $\left(\mathrm{t}_{1 / 2}\right)$ with respect to oxidation and on mass transport by turbulent mixing. The mixing lengths of $\mathrm{Mn}$, i.e. the distance dissolved or colloidal $\mathrm{Mn}$ can be transported before reprecipitation occurs, can be estimated by $\left(\mathrm{K}_{i} * \tau\right)^{0.5}$, where $\mathrm{K}_{i}$ denotes a turbulent diffusion coefficient and $\tau$ is the characteristic residence time. The turbulent diffusion coefficients for vertical and horizontal mass transport in lakes are approximately $\mathrm{K}_{v} \leq$ $10^{-6} \mathrm{~m}^{2} \mathrm{~s}^{-1}$ and $\mathrm{K}_{h}=0.02-0.3 \mathrm{~m}^{2} \mathrm{~s}^{-1}$ respectively (Peeters et al., 1996; Wüest et al., 1996). The characteristic residence time can be calculated from the half life by $\tau=\ln 2 * \mathrm{t}_{1 / 2}$, assuming that the elimination of Mn from the water-column by oxidation and subsequent reprecipitation can be described by a pseudo first order reaction with rate constant $\mathrm{K}$ and $\tau=1 / \mathrm{K}$. The half life of manganese in such systems has been determined as 1-100 days (Chappnik et al., 1982; Wehrli et al., 1995a), where the lower boundary of $t_{1 / 2}=1$ day is characteristic for eutrophic lakes. In Sempachersee Wehrli et al. (1995a) determined a half life of 1.4 days. Since Baldeggersee has approximately the same geochemical conditions and the same trophic state as Sempachersee we use this half life for the calculation of the mixing lengths. Horizontal and vertical mixing length would then be in the order of 60-200 m and $0.4 \mathrm{~m}$, respectively. Comparing the two scales we assume that dissolved Mn (II) released from the sediments will be efficiently mixed horizontally over the lake before oxidation and subsequent sedimentation occurs. Therefore manganese diffusing out of the sediments at the near shore region will at least partly be redeposited at deeper sites of the lake. Whereas manganese diffusing out of the sediment in the deeper parts will be oxidised before it is vertically transported and the probability for it being deposited at shallower regions is very low. Consequently an average "flux" of manganese from the shore regions to the deeper parts of the lake takes place.

This conceptual model points out that: (1) even in the absence of mass transport features caused by inflows or very short hydraulic residence times, distinct horizontal patterns of sedimentary Mn concentrations can be established, (2) patterns are triggered by the difference between horizontal and vertical mass transport due to turbulent mixing and by specific oxygen conditions in the deep-water, (3) the patterns can be assigned to specific oxygen conditions in the deep-water.

\section{Regression Analysis}

So far, the model for a geochemical-focusing is based on mainly qualitative aspects. The goal of this section is to validate the focusing model of manganese on a statistical basis. 


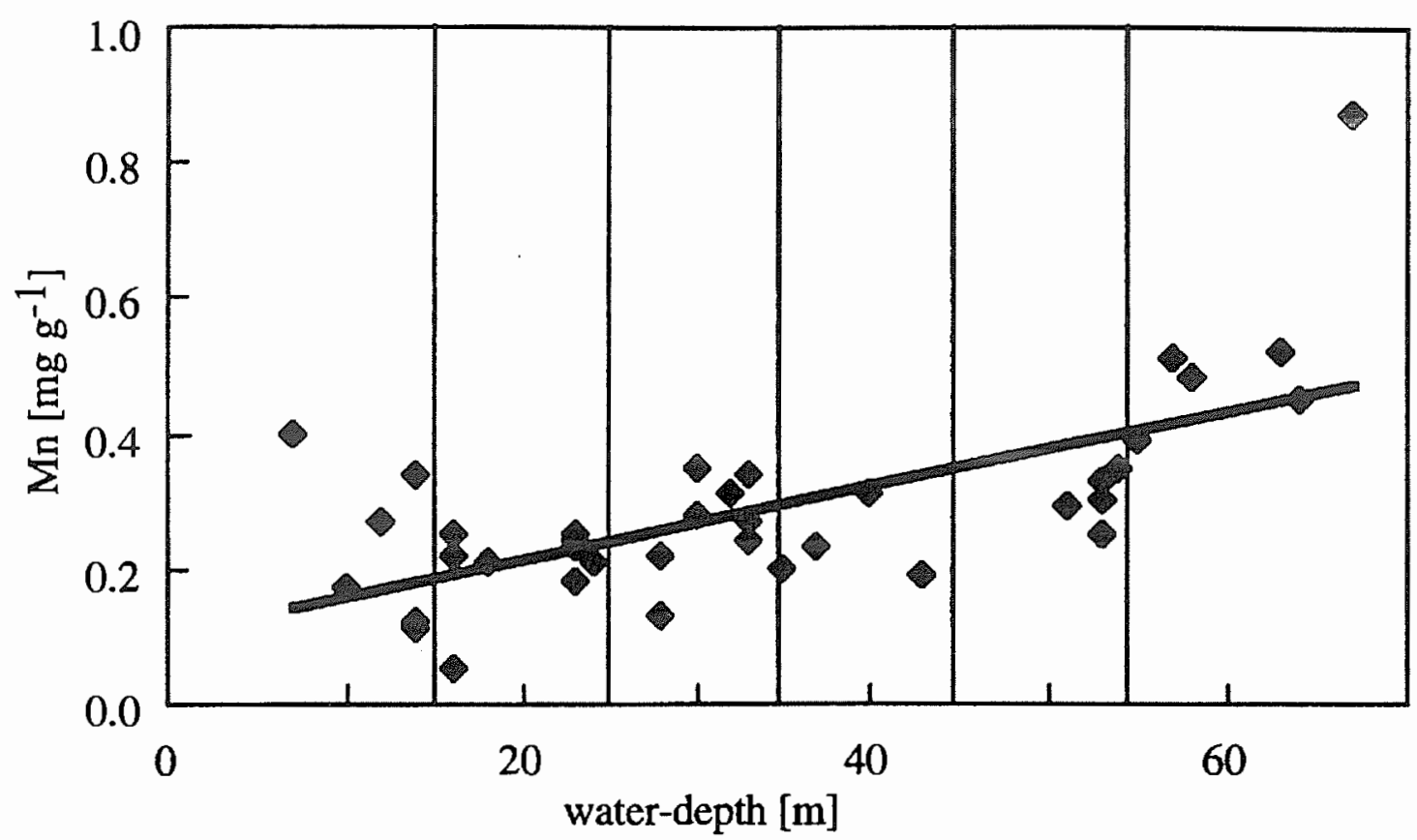

Figure 8. Mn concentrations plotted against water-depth for highly eutrophic lake conditions in Baldeggersee. Vertical lines separate the water-depth ranges which were used in Figure 9 to average Mn-concentrations.

Figure 8 shows Mn concentrations in the sediment as a function of water-depth for the highly eutrophic conditions of Baldeggersee corresponding to the $10-40 \mathrm{~cm}$ zone in Figure 2. An increase of Mn concentrations with water-depth is observed. For both regression parameters the slope (regression coefficient) and the coefficient of determination, the null hypothesis (slope $=0, \mathrm{r}^{2}=0$ ) must be rejected on a 95\% confidence level ( $\mathrm{p} \ll 0.05)$. The same statements hold for the artificially aerated state. On the other hand, for the mesotrophic state the null hypothesis for the regression coefficient $(p>0.05)$ and the coefficient of determination $(p>0.05)$ cannot be rejected. With the regression analysis we can confirm for Baldeggersee that a statistically significant increase of Mn concentrations with water-depth only occurs during eutrophic and artificially aerated lake conditions. The higher regression coefficient $(0.007)$ and the better correlation $(0.75)$ for the artificially aerated situation give evidence of a stronger dependence of the Mn concentrations of water-depth during the artificially aerated state than during the eutrophic situation (regression coeff. $=0.005$, corr. $=0.66$ ).

Geochemical focusing of $\mathrm{Mn}$ is driven by the release of $\mathrm{Mn}^{2+}$ from anoxic sediments. At a given depth $\mathrm{z}$ in a lake only the sediments at shallower depths with the area $\int_{0}^{z} A(z) d z$ contribute to geochemical-focusing (the morphometric function $A(z)$ describes the sediment area as a function of depth). Thus by assuming that, on an average scale of several years, seasonal variations in the manganese cycling and mixing conditions are negligible, sedimentary Mn concentration should be proportional to the area of shallower sediments, where geochemical-focusing occurs. The samples of Baldeggersee integrate concentrations of 4-6 years. In Figure $9 \mathrm{a}$ the results of the regression of $\mathrm{Mn}$ concentrations as a function of 

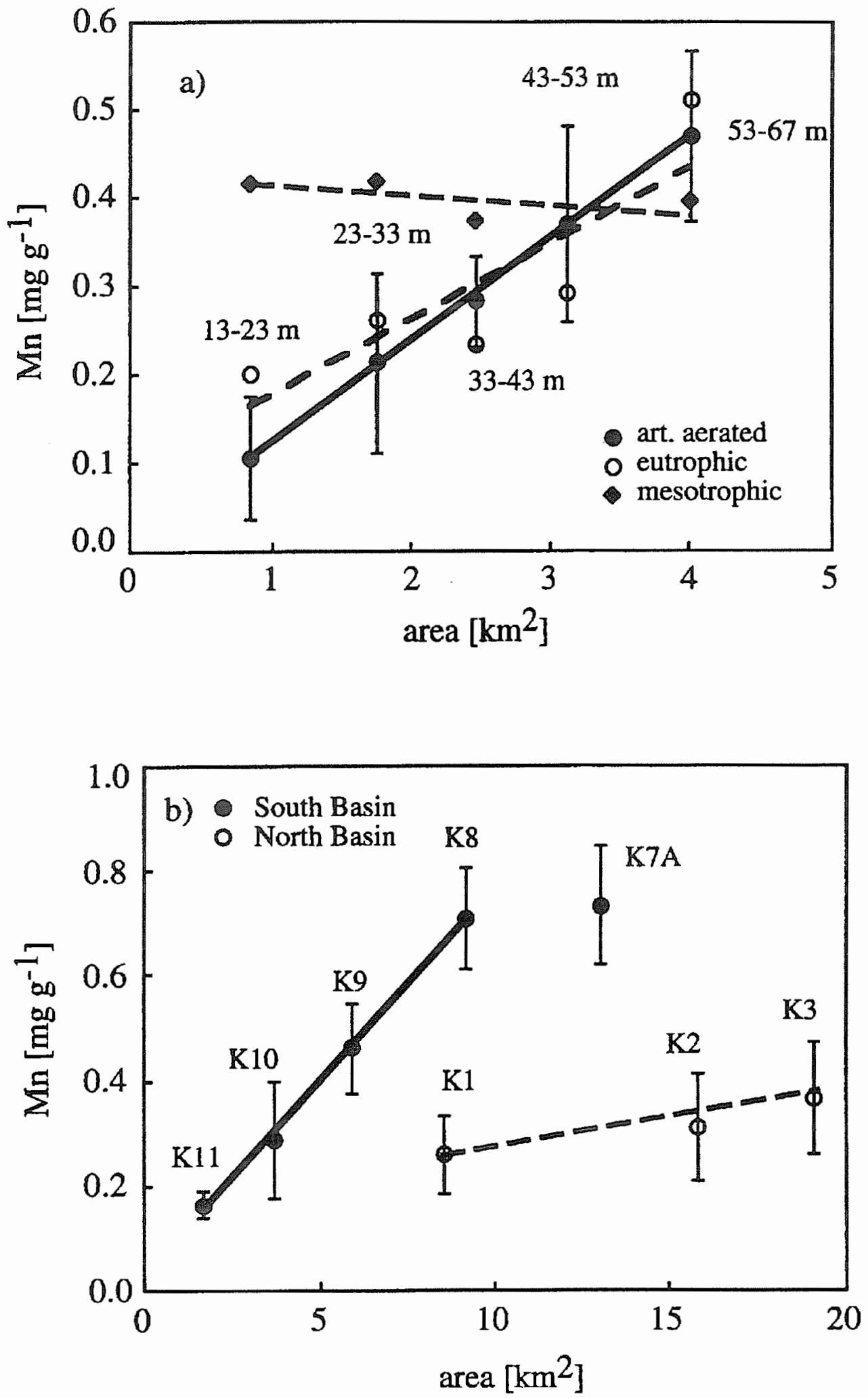

Figure 9. Average Mn concentrations at specific water-depth ranges plotted against the area of shallower sediments at Baldeggersee (a) and Zugersee (b). The sediment surface areas are defined by the depth isolines at $0,13,23,33,43,53$ and $67 \mathrm{~m}$ for Baldeggersee and by isolines at $0,40,76,120,158$ and $190 \mathrm{~m}$ for Zugersee. For Baldeggersee the concentrations are calculated as average of the cores situated between the respective isolines. For the artificially aerated lake conditions, standard deviations are presented. The standard deviations for the two other lake conditions are of the same order of magnitude. 
Table II. Calculated values of $\mathrm{dMn} / \mathrm{dA}$ for Zugersee (North and South Basin) and Baldeggersee (different lake conditions)

\begin{tabular}{lc}
\hline & $\mathrm{dMn} / \mathrm{dA}\left(\mathrm{mg} \mathrm{g}^{-1} \mathrm{~km}^{-2}\right)$ \\
\hline Zugersee & \\
North Basin & 0.01 \\
South Basin & 0.07 \\
Baldeggersee & \\
mesotrophic & -0.01 \\
eutrophic & 0.09 \\
artificially aerated & 0.12 \\
\hline
\end{tabular}

the sediment surface area under the three different oxygen regimes are given. For regression the sediment surface area was split into six subareas, defined by the depth isolines $0,13,23,33,43,53$ and $67 \mathrm{~m}$. For each subarea averaged values were calculated from the concentrations of the cores situated between two respective isolines. The near shore zone ( $0-13 \mathrm{~m}$ depth) was omitted, because coarse-grained soil particles from the catchment may influence the $\mathrm{Mn}$ accumulation rate to a great extent. From the linear fits we obtain values of $\mathrm{dMn} / \mathrm{dA}$ of $0.09 \mathrm{mg} \mathrm{g}^{-1} \mathrm{~km}^{-2}$ and $0.12 \mathrm{mg} \mathrm{g}^{-1} \mathrm{~km}^{-2}$ for the eutrophic and the artificially aerated lake respectively.

Figure $9 \mathrm{~b}$ shows the results of Zugersee: Average $\mathrm{Mn}$ concentrations from each core are plotted against the area of shallower sediments. The isolines for the calculation of the sediment surface areas were defined by the depth of the cores $(40,76$, $120,158,190 \mathrm{~m}$ ). Both transects show a positive linear correlation between average Mn concentrations at a specific water-depth and the area of shallower sediments. Core 4 and core 5 from the North Basin were omitted, since bottom currents have a great influence on the sedimentation rates. Core 7A in the South Basin does not show the same proportionality to the sediment surface as the other cores from the transect. Since the oxycline in the deepest part of the South Basin is well above the sediment-water interface $(\sim 40 \mathrm{~m})$ an effective vertical transport of dissolved $\mathrm{Mn}(\mathrm{II})$ is possible, which inhibits further geochemical-focusing. Calculated values of $\mathrm{dMn} / \mathrm{dA}$ are very different for the North Basin $\left(0.01 \mathrm{mg} \mathrm{g}^{-1} \mathrm{~km}^{-2}\right)$ and the South Basin $\left(0.07 \mathrm{mg} \mathrm{g}^{-1} \mathrm{~km}^{-2}\right)$.

Table II presents values of $\mathrm{dMn} / \mathrm{dA}$ for Zugersee and Baldeggersee. The values calculated for the three different conditions of Baldeggersee indicate that the geochemical-focusing only occurs if intense manganese cycling can be expected. The effect is most pronounced in the case where an anoxic sediment is in contact with an oxic water-column. The values determined for the two basins of Zugersee indicate that the intensity of the geochemical focusing, expressed as $\mathrm{dMn} / \mathrm{dA}$, can vary considerably, although both basins have comparable oxygen conditions. We suppose, that the observed difference is due to the morphology, i.e. the sediment surface as a function of water-depth, of the two basins. 


\section{Conclusions}

It has been shown that the distribution of $\mathrm{Mn}$ concentrations in the sediments of two deep, eutrophic lakes with long hydraulic residence times strongly depends on the redox conditions of both the sediment and the deep-water. If an anoxic sediment is in contact with an oxic water-column, geochemical-focusing of manganese occurs resulting in an increase of $\mathrm{Mn}$ concentrations at the deepest part of the lake and simultaneously in a decrease of concentrations at the shallow parts. The increase of $\mathrm{Mn}$ concentrations with water-depth is directly proportional to the increase of sediment surface area with depth. The relation between sediment surface area and $\mathrm{Mn}$ concentrations can be a useful tool for the reconstruction of past oxygen budgets of deep lakes, where inflow and outflow do not highly affect the mass transport of dissolved and particulate manganese.

\section{Acknowledgements}

We thank A. Zwyssig and G. Friedl for help with field work, E. Grieder and D. Kistler for help in the laboratory, G. Friedl, M. Gloor, M. Mengis, B. Müller, M. Sturm and A. Wüest for fruitful discussions and R. Gächter, W. Schumacher and A. Wüest for critical reading. This work was supported by a research grant from the "Schweizerischer Nationalfonds" (NFP-31 grant 4031-33147).

\section{References}

Balistrieri, L. S., Murray, J. W. and Paul, B. (1992) The cycling of iron and manganese in the water column of Lake Sammamish, Washington. Limnol. Oceanogr. 37, 510-528.

Calvert, S. E. and Pedersen, T. F. (1993) Geochemistry of recent oxic and anoxic marine sediments: Implications for the geological record. Marine Geology 113, 67-88.

Calvert, S. E. and Price, N. B. (1977) Geochemical variation in ferromanganese nodules and associated sediments from the Pacific Ocean. Mar. Chem. 5, 43-74.

Chapnick, S. D., Moore, W. S. and Nealson, K. H. (1982) Microbially mediated manganese oxidation in a freshwater lake. Limnol. Oceanogr. 27, 1004-1014.

Davison, W. (1993) Iron and manganese in lakes. Earth-Science Reviews 34, 119-163.

Davison, W. and Woof, C. (1984) A study of the cycling of manganese in a seasonally anoxic lake, Rostherne Mere, U. K. Water Res. 18, 727-734.

Davison, W., Woof, C. and Rigg, E. (1982) The dynamics of iron and manganese in a seasonally anoxic lake; direct measurement of fluxes using sediment traps. Limnol. Oceanogr. 27, 987-1003.

Dean, W. E., Moore, W. S. and Nealson, K. H. (1981) Manganese cycles and the origin of manganese nodules, Oneida Lake, New York, USA. Chem. Geol. 34, 53-64.

De Vitre, R. R., Buffle, J., Perret, D., et al. (1988) A study of iron and manganese transformations at the $\mathrm{O}_{2} / \mathrm{S}(-\mathrm{II})$ transition layer in a eutrophic lake (Lake Bret, Switzerland): A multimethod approach. Geochim. Cosmochim. Acta 52, 1601-1613.

François, R. (1988) A Study on the regulation of the concentrations of some trace metals (Rb, $\mathrm{Sr}, \mathrm{Zn}$, $\mathrm{Pb}, \mathrm{Cu}, \mathrm{V}, \mathrm{Cr}, \mathrm{Ni}, \mathrm{Mn}$ and $\mathrm{Mo}$ ) in Saanich Inlet sediments, British Columbia, Canada. Marine Geology 83, 285-308.

Friedl, G., Wehrli, B. and Manceau, A. (1996) The role of solids in the cycling of manganese in eutrophic lakes - New insights from EXAFS-spectroscopy. Geochim. Cosmochim. Acta (accepted).

Hamilton-Taylor, J. and Morris, E. B. (1985) The dynamics of iron and manganese in the surface sediments of a seasonally anoxic lake. Arch. Hydrobiol. Suppl. 72, 135-165. 
Jödike, G. (1996) Proxydaten aus reduzierten schwefelverbindungen in seesedimenten. Diploma thesis ETH-Zürich.

Kelts, K. (1978) Geological and sedimentary evolution of lakes Zürich and Zug, Switzerland. Ph.D.thesis. ETH-Zürich.

Kelts, K., Briegel, U., Ghilarde, K., et al. (1986) The limnology-ETH coring system. Schweiz. Z. für Hydrologie 48, 104-115.

Lind, C. J., Hem, J. D. and Roberson, C. E. (1987) Reaction products of manganese bearing waters. In Chemical Quality of Water and the Hydrological Cycle. (eds. R. C. Averett and McKnight, D. M.). pp. 273-301. Chelsea, Michigan, Lewis.

Mengis, M., Bernasconi, S., Gächter, R., Wehrli, B. (submitted) Nitrogen-elimination in two eutrophic lakes. Limnol. Oceanogr.

Moor, H. C., Schaller, T., Sturm, M. (1996) Recent changes in stable lead isotope ratios in sediments of Lake Zug, Switzerland. Env. Sci. Techn. 30(10), 2928-2933.

Niessen, F. and Sturm, M. (1987) The sediments of lake Baldegg (Switzerland) - Sedimentary environment and development of eutrophication for the last 100 years. Arch. Hydrobiol. 108, 365-383.

Peeters, F., Wüest, A., Piepke, G., et al. (1996) Horizontal mixing in lakes. J. Geophys. Res. 101(C8), 18361-18375.

Ostendorp, W. and Frevert, T. (1979) Untersuchungen zur Manganfreisetzung und zum Mangangehalt der Sedimentoberschicht im Bodensee. Arch. Hydrobiol. Suppl. 55, 255-277.

Spencer, D. W. and Brewer, P. G. (1971) Vertical advection diffusion and redox potentials as controls of the distribution of manganese and other trace metals dissolved in waters of the Black Sea. $J$. Geophys. Res. 76, 5877.

Spengeler, R. (1994) Die Sanierung des Baldeggersees: Besiedelung des Benthals durch Oligochaeten und Chironomiden 12 Jahre nach Beginn der seeinternen Massnahmen. Diploma thesis ETHZürich.

Takamatsu, T., Kawashima, M. and Kogana, M. (1985) Manganese concentrations in the sediment as an indicater of water-depth, paleo-water-depth during the last few million years. Kokuristu Kogai Kenkyusho Kenkyu Hokoku 75, 63-67.

Tessenow, T. (1975) Lösungs-, Diffusions- und Sorptionsprozesse in der Oberschicht von Seesedimenten. V. Die Differenzierung der Profundalsedimente eines oligotrophen Bergsees (Feldsee, Hochschwarzwald) durch Sediment-Wasser-Wechselwirkungen. Arch. Hydrobiol. Suppl. $47,325-412$.

Thamdrup, B., Glud, R. N. and Hansen, J. W. (1994) Manganese oxidation and in situ manganese fluxes from a coastal sediment. Geochim. Cosmochim. Acta 58, 2563-2570.

Tipping, E., Thomson, D. W. and Davison, W. (1984) Oxidation products of Mn(II) in lake waters. Chem. Geol. 44, 359-383.

Urban, N. R., Dinkel, C. and Wehrli, B. (submitted) Solute transfer across the sediment surface of a eutrophic lake: I. Porewater profiles from dialysis samplers. Aquatic Sciences.

Wehrli, B., Friedl, G. and Manceau, A. (1995a) Reaction rates of products of manganese oxidation at the sediment water interface. In: Aquatic Chemistry: Principles and Applications of Interfacial and Inter-Species Interactions in Aquatic Systems. (eds. C. P. Huang, C. O'Melia and J. J. Morgan) pp. 111-134. Washington, Amer. Chem. Soc.

Wehrli, B., Wüest, A. and Imboden, D. M. (1995b) Sind biogen meromiktische Seen intern sanierbar? Fallbeispiel Zugersee. In: Verfahren zur Sanierung und Restaurierung stehender Gewässer (eds. Jaeger, D. and Koschel, R.) pp: 29-37. Stuttgart, Jena, New York, Gustav Fischer Verlag.

Wüest, A., van Senden, D. C., Imberger, J., et al. (1996) Comparison of diapycnal diffusivity measured by tracer and microstructure techniques. Dynamics of Atmosphere and Oceans 24: 27-39. 